\title{
CHARACTERISTICS OF THE VAGINAL MICROBIOTA, CERVICAL AND UTERINE FLORA IN WOMEN WITH THE PAST HISTORY OF SEXUALLY TRANSMITTED INFECTIONS
}

DOI: 10.36740/WLek202104116

\author{
Olena I. Krotik \\ SHUPYK NATIONAL MEDICAL ACADEMY OF POSTGRADUATE EDUCATION OF THE MINISTRY OF HEALTH OF UKRAINE, KYIV, UKRAINE
}

\begin{abstract}
The aim: To identify the characteristics of the vaginal microbiota, cervical and uterine flora in women with the past history of sexually transmitted infections.

Materials and methods: A prospective study and the analysis of the vaginal microbiota, cervical and uterine flora were conducted in 96 women of reproductive age with infertility after the past history of STIs, who planned to get pregnant using ART. Together they made up the group I (main group) and the CG included 30 women of reproductive age, who planned pregnancy without a compromised reproductive history.

Results: Nonspecific vulvovaginitis ( $X 2=31.6 ; p<0.001)$ was diagnosed in $63(63.6 \%)$ patients of the group I, vulvovaginal candidiasis - in 17 (17.7\%). Lactobacilli in a vaginal discharge in representatives of the $C G$ and group I $-96.7 \%$ and $29.1 \%$, respectively $(x 2=20.3 ; p<0.001)$. Opportunistic pathogens, BV-associated microorganisms and obligate anaerobes in the next titers: $10 \times 5 \mathrm{CFU} / \mathrm{ml}$ and higher, $\mathrm{CG}<10 \times 3 \mathrm{CFU} / \mathrm{ml}$ were found in $68(70.8 \%)$ women of the group I. N. gonorrhoeae was detected in $2(2.1 \%)$ patients of the group I. An intense leukemoid reaction - in 59 (61.5\%) women of the group I. The rate of cervical contamination with these pathogens ranged from 10x3 to $10 \times 4 \mathrm{CFU} / \mathrm{ml}$ in 35 (36.5\%) women of the group I, in 61 (63.5\%) - titers of opportunistic pathogens were > 10x4 CFU/ml. Pathogenic bacteria of the cervical canal, represented by obligate anaerobes, was detected in 70 (72.9\%) cases, where 11 (11.4\%) patients were diagnosed with Chlamydia trachomatis, 2 (2.1\%) - N.gonorrhoeae. Chlamydia trachomatis and Mycoplasma genitalium were registered in $11(11.5 \%)$ and 19 (19.8\%) cases, respectively, and were not detected in controls. Ureaplasma urealyticum in the cervical canal outnumbered the diagnostic level in women: $17.7 \%$ - group I and 6.7\% - CG, respectively $(X 2=7.9 ; \mathrm{p}<0.01)$. N.gonorrhoeae and Trich. vaginalis were detected in $2.1 \%$ and $6.25 \%$ of women in the group I, respectively. Persistent urogenital infection - the combination of opportunistic and common pathogens - prevailed in 59 (60.2\%). Associations of obligate anaerobes and Chlamydia trachomatis were found in 69 (71.8\%) of them, microaerophiles - in $29(30.2 \%)$, the combination of various species of opportunistic pathogens - in $14(14.6 \%)$; the growth of monocultures of opportunistic pathogens, in titers coming to $10^{6}-10^{8}$, was recognized in 19 (19.8\%). The growth of monoculture, represented by group B Streptococcus was detected in 8 (8.3\%) cases, Enterococcus faecalis - in 12 (12.5\%), Mycoplasma genitalium - in 17 (17.7\%). The analysis of PCR test results enabled to detect associations of different species of viruses with Myco-and Ureaplasma, Chlamydia in $23(23.9 \%)$ patients of the group I. What should be noted is the predominance of Herpes simplex over CMV infection: 7 (7.3\%) and $2(2.1 \%)$, respectively $(p<0.05)$.

Conclusions: The predominance of the mixed microbiota, represented by various associations of opportunistic and common pathogens, was identified in infertile women with the past history of STIs as a result of microbial culturing of the samples from the uterine cavity. Chronic inflammation in endometrium is caused by a persistent viral-bacterial infection in the uterine cavity, which differs in the species composition from the microbiota of the lower genital tract.
\end{abstract}

KEY WORDS: sexually transmitted infections (STIs), pelvic inflammatory disease, infertility, microbiota, assisted reproductive technologies

Wiad Lek. 2021;74(4):896-901

\section{INTRODUCTION}

Sexually transmitted infections (STIs) deeply affect sexual and reproductive health worldwide and are ranked among top 5 disease categories, in case of which adults usually seek medical care [1,2]. More than 1 million people get a sexually transmitted infection daily. It is estimated that 500 million people annually get one of four STIs: chlamydia infection, gonorrhea, syphilis and trichomoniasis. More than 530 million people have HSV-2 [3].

In particular cases, STIs can have serious consequences for reproductive health in addition to the direct effects of the infection itself $[3,4-6]$. STIs such as gonorrhea and chlamydia infection are the leading causes of pelvic inflammatory disease, unfavorable outcomes of pregnancy and infertility (WHO, 2018). And also tend to be the common cause of failures in case of using assisted reproductive technologies (ART) [7].

As for the complications in case of infecting with sexually transmitted pathogens, the first thing to be considered is impacted fertility represented by tubo-peritoneal, endocrine and uterine factor infertility. Tubo-peritoneal factor infertility appears due to structural or functional disorder of tubal patency as a result of inflammation. Endocrine factor infertility - due to ovulatory dysfunction and luteal insufficiency, occurring in case of oophoritis. Uterine factor infertility - due to abnormal endometrial maturation in case of endometritis. Ectopic pregnancy and complications in intrauterine pregnancy in the form of habitual miscarriage (13-25\%), prelabor rupture of membranes, premature birth, postpartum endometritis, chorioamnionitis and placental inflammation, perinatal infection 
Table I. Vaginal microbiota in patients examined (abs. n., \%)

\begin{tabular}{|c|c|c|c|c|c|c|}
\hline \multirow[t]{2}{*}{ State of microbiota } & \multicolumn{2}{|c|}{$\begin{array}{c}\text { CG } \\
n=30\end{array}$} & \multicolumn{2}{|c|}{$\begin{array}{c}\text { Group I } \\
n=96\end{array}$} & \multirow[t]{2}{*}{$x^{2}$} & \multirow[t]{2}{*}{$\mathbf{P}$} \\
\hline & Abs. $n$. & $\%$ & Abs. $n$. & $\%$ & & \\
\hline Normal microbiota & 25 & 83.3 & 6 & 6.2 & 80.1 & $<0.001$ \\
\hline Intermediate type & 2 & 6.7 & 5 & 5.2 & 29.4 & $<0.001$ \\
\hline Bacterial vaginosis & 2 & 6.7 & 5 & 5.2 & 0.78 & $>0.1$ \\
\hline Nonspecific vulvovaginitis & 1 & 3.4 & 63 & 63.6 & 31.6 & $<0.001$ \\
\hline Vulvovaginal candidiasis & - & - & 17 & 17.7 & - & - \\
\hline
\end{tabular}

Table II. Microbiota of the vaginal discharge in patients examined (abs. n., \%)

\begin{tabular}{|c|c|c|c|c|c|c|}
\hline \multirow[t]{2}{*}{ Microbiota } & \multicolumn{2}{|c|}{$\begin{array}{c}\text { CG } \\
n=30\end{array}$} & \multicolumn{2}{|c|}{$\begin{array}{c}\text { Group I } \\
\mathbf{n}=96\end{array}$} & \multirow[t]{2}{*}{$x^{2}{ }^{2}$} & \multirow[t]{2}{*}{$\mathbf{P}$} \\
\hline & Abs. $\mathbf{n}$. & $\%$ & Abs. $\mathrm{n}$. & $\%$ & & \\
\hline Lactobacillus sp. & 29 & 96.7 & 28 & 29.1 & 20.3 & $<0.001$ \\
\hline Corynebacterium sp. & 17 & 56.7 & 34 & 35.4 & 4.62 & $<0.05$ \\
\hline Candida albicans & - & - & 10 & 10.4 & - & - \\
\hline Bacteroides sp. & 7 & 23.3 & 44 & 45.8 & 4.5 & $<0.05$ \\
\hline Staphylococcus sp. & 9 & 30.0 & 53 & 55.2 & 4.48 & $<0.05$ \\
\hline Gardnerella vaginalis & 10 & 33.3 & 56 & 58.3 & 4.35 & $<0.05$ \\
\hline Mobyluncus & 3 & 10.0 & 25 & 26.0 & 3.94 & $<0.05$ \\
\hline N.gonorrhoea & - & - & 2 & 2.1 & - & - \\
\hline Prevotella & 10 & 33.3 & 43 & 44.8 & 5.5 & $<0.05$ \\
\hline Peptostreptococcus sp. & 6 & 20.0 & 45 & 46.9 & 5.9 & $<0.05$ \\
\hline Streptococcus sp.B & 10 & 33.3 & 54 & 56.25 & 3.97 & $<0.05$ \\
\hline Enterococcus sp. & 11 & 36.7 & 44 & 45.8 & 4.07 & $<0.05$ \\
\hline Enterococcus faecalis & 11 & 36.7 & 41 & 42.7 & 5.62 & $<0.05$ \\
\hline E. coli & - & - & 9 & 9.4 & - & - \\
\hline Atopobium vaginae & - & - & 9 & 9.4 & - & - \\
\hline
\end{tabular}

Table III. Microbiota of the cervical canal in women examined (abs.n., \%)

\begin{tabular}{|c|c|c|c|c|c|c|}
\hline \multirow[t]{2}{*}{ Microscopic examination } & \multicolumn{2}{|c|}{$\begin{array}{c}\text { CG } \\
n=30\end{array}$} & \multicolumn{2}{|c|}{$\begin{array}{c}\text { Group I } \\
\mathbf{n}=96\end{array}$} & \multirow{2}{*}{$x^{2}$} & \multirow[t]{2}{*}{$\mathbf{P}$} \\
\hline & Abs. $\mathbf{n}$. & $\%$ & Abs. $\mathbf{n}$. & $\%$ & & \\
\hline Leukocytes up to 10 in the field of view & 27 & 90.0 & 37 & 38.5 & 26.4 & $<0.001$ \\
\hline Leukocytes $>25$ in the field of view & 3 & 10.0 & 59 & 61.5 & 6.75 & $<0.01$ \\
\hline
\end{tabular}

$(8-12 \%)$ and stillbirth happen at times $[8,9]$. Mother-to-child transmission of STIs can lead to stillbirth, neonatal death, low birth weight, prematurity, sepsis, pneumonia, neonatal conjunctivitis, and birth defects [9-11].

Thus, research on characteristics of the vaginal microbiota, cervical and uterine flora in women with the past history of sexually transmitted infections will enhance the effectiveness pre-pregnancy care before ART cycles in order to recover reproductive health in patients of this group.

\section{THE AIM}

To identify the characteristics of the vaginal microbiota, cervical and uterine flora in women with the past history of sexually transmitted infections, who are planning to implement their reproductive function by means of ART programs, were studied and analyzed.

\section{MATERIALS AND METHODS}

We examined 96 infertile women of reproductive age with the past history of STIs, who planned pregnancy assisted by ART, at the clinical site of Kyiv City Center for Reproductive and Perinatal Medicine over the period of 2018-2020 (clinical site of the department of Obstetrics, Gynecology and Reproductology of Shypuk NMAPE of the Ministry of Health of Ukraine). They comprised the group I (main group) and CG included 30 women of reproductive age, 
who are planning pregnancy without a compromised reproductive history.

When studying the mocrobiota of the genital tract we stuck to the step-by-step approach: vagina, cervical canal, uterine cavity (endometrium). A comprehensive microbiological analysis, involving microscopy of gram- stained smears, culturing and molecular DNA analysis of sexually transmitted pathogens using PCR enabled to assess the spectrum of pathogens.

\section{RESULTS}

In order to study the etiology of inflammation in the uterine cavity, a comprehensive microbiological analysis of the vaginal and cervical discharge was conducted in all women examined. The vaginal microbiota was assessed according to a comprehensive microbiological analysis of the vaginal discharge. The microbiota in a gram-stained vaginal smear was assessed and cultured (Tables I and II).

In controls in 25 (83.3\%) cases, microecological parameters of a vaginal smear complied with the standards of the reproductive age range: first-degree purity of the vaginal smear was identified when assessing the microbiota, leukocyte number was less than 10 in the field of view, the epithelium was represented by cells of superficial and intermediate layers. The microbiota was homogenous in composition (only Lactobacillus morphotypes prevailed) and medium in number (right up to 100 microbial cells in the field of view). Nonspecific vulvovaginitis $(\chi 2=31.6$; $\mathrm{p}<0.001)$ was diagnosed in $63(63.6 \%)$ patients of the group $\mathrm{I}$, the findings in smears were indicative of vulvovaginal candidiasis in 17 (17.7\%). The rate of bacterial vaginosis in both groups of patients was not distinctive $\left(\chi^{2}=0.78\right.$; $\mathrm{p}>0.10$ ).

In patients from the CG when culturing a vaginal discharge, Lactobacilli were predominant in contrast to the findings in the group I: $96.7 \%$ and $29.1 \%$, respectively $(\chi 2=$ $20.3 ; \mathrm{p}<0.001)$. Among patients of the CG, Lactobacilli were isolated from the monoculture in $6(20.0 \%)$, in 23 $(76.7 \%)$ lactic acid bacteria were isolated as the association with opportunistic pathogens, the titers of which did not exceed 103-104 CFU/ml: enterococci were registered in $11(36.7 \%)$ patients, corynebacteria in 17 (56.7\%), staphylococci in $9(30.0 \%)$, group B Streptococcus in $10(33.3 \%)$.

In $68(70.8 \%)$ infertile women with the past history of STIs, the specimen composition of the vaginal microbiota was characterized by a significant decrease in the frequency of lactobacillus isolation, in association with the positive growth of facultative anaerobes, which comprise opportunistic pathogens (staphylococci, streptococci, $B V$-associated microorganisms (Gardnerella, Mobilincus, Atopobium vaginae) and obligate anaerobes (bacteroids, peptostreptococci, fusobacteria) in elevated titers coming to $105 \mathrm{CFU} / \mathrm{ml}$ and higher, as compared to the values in the CG, where the titers of opportunistic pathogens did not exceed $103 \mathrm{CFU} / \mathrm{ml}$. N. gonorrhoeae was detected in $2(2.1 \%)$ patients of the group I, while neither case in women of the CG.
A comprehensive microbiological analysis of the cervical discharge in patients of both groups consisted of microscopic, microbial culturing and the assessment of the specimen composition of pathogens by means of the PCR test. Tables III and IV represent the results of microscopic examination of the cervical discharge, sum frequency of microorganism isolation, qualitative and quantitative composition of the microbiota of the cervical canal.

Thus, an intense leukemoid reaction was observed in 59 (61.5\%) infertile women with the past history of STIs. It significantly differs from equivalent parameters in women from the CG, who, in 27 (90.0\%) cases, had the number of leukocytes up to 10 in the field of view $(\chi 2=26.4 ; p<0.001)$. Microbial culturing of the cervical discharge indicated that the growth of microbiota in all samples was not detected. The growth of opportunistic pathogens, originating from facultative anaerobes, was diagnosed in all cases of $\mathrm{mi}-$ crobial culturing in patients of the group I. In 21 (21.4\%) of these patients, the cervical microbiota was represented by monocultures of group B Streptococcus, in 19 (19.8\%) - Enterococcus faecalis, in $21(21.9 \%)$ - as a part of the associations of opportunistic pathogens. The quantitative assessment showed that the rate of cervical colonization with these pathogens ranged from 103 to $104 \mathrm{CFU} / \mathrm{ml}$ in 35 (36.5\%) women of the group I, titers of opportunistic pathogens were increased (>104 CFU/ml) in 61 (63.5\%). Pathogens, represented by obligate anaerobes, were found in $70(72.9 \%)$ cases in the process of culturing the cervical discharge, and Chlamydia trachomatis was found in 11 $(11.4 \%)$ of these cases in the group I, N.gonorrhoeae - in $2(2.1 \%)$.

The findings of the PCR test, when studying the species composition of microorganisms in the cervical canal, indicate the high frequency of detecting pathogens associated with STIs in patients of the group I, comparing to the findings in patients of the CG. The cases when Chlamydia trachomatis and Mycoplasma genitalium were registered came to $11(11.5 \%)$ and $19(19.8 \%)$, respectively, while they were not detected in controls. The rate of cervical contamination with Ureaplasma urealyticum, based on the findings of the PCR test, outnumbered the diagnostic level in women: $17.7 \%$ - group I and $6.7 \%$ - CG, respectively ( $\chi^{2}=7.9$; $\mathrm{p}<0.01)$. N.gonorrhoeae and Trich. vaginalis were detected in $2.1 \%$ and $6.25 \%$ of women of the group I, respectively. The frequency of human papillomavirus in women of both groups was not distinctive $(\mathrm{p}>0.05)($ Table $\mathrm{V})$.

The microbiome of an endometrial biopsy in the main group was assessed by means of culturing and the PCR test. When assessing the findings of a microbiological analysis in infertile women with the past history of STIs, endometrial urogenital infection was found in endometrial samples in all cases, however the species composition of microorganisms differed from those detected in the vaginal and cervical discharge.

When culturing the content of the uterine cavity (Table VI), persistent urogenital infection was found to prevail in $59(60.2 \%)$ cases. It was represented by various combinations of opportunistic and common pathogens. Asso- 
Table IV. Microbiota of the cervical canal in patients of the group I (abs. n., \%)

\begin{tabular}{|c|c|c|}
\hline \multirow{2}{*}{ Types of microorganisms } & \multicolumn{2}{|c|}{ Group I n=96 } \\
\hline & Abs. $n$. & $\%$ \\
\hline Group B Streptococcus & 19 & 19.8 \\
\hline Enterococcus faecalis & 21 & 21.9 \\
\hline Group B Streptococcus + Enterococcus faecalis & 23 & 23.9 \\
\hline Prevotella melaninogenica & 28 & 29.1 \\
\hline Peptostreptococcus sp.+Prevotella melaninogenica & 31 & 32.3 \\
\hline Chlamydia trachomatis & 11 & 11.4 \\
\hline Ureaplasma urealyticum & 49 & 51.0 \\
\hline Mycoplasma genitalium & 18 & 18.7 \\
\hline N.gonorrhoeae & 2 & 2.1 \\
\hline
\end{tabular}

Table V. PCR test of the cervical discharge in women examined (abs. n., \%)

\begin{tabular}{|c|c|c|c|c|c|c|}
\hline \multirow{2}{*}{ Microbiota } & \multicolumn{2}{|c|}{ CG $n=30$} & \multicolumn{2}{|c|}{ Group I n=96 } & \multirow{2}{*}{$x^{2}$} & \multirow{2}{*}{$\mathbf{P}$} \\
\hline & Abs. $n$. & $\%$ & Abs. $n$. & $\%$ & & \\
\hline Trichomonas vaginalis & - & - & 6 & 6.25 & - & - \\
\hline Chlamydia trachomatis & - & - & 11 & 11.5 & - & - \\
\hline Ureaplasma urealyticum & 2 & 6.7 & 17 & 17.7 & 7.9 & $<0.01$ \\
\hline Mycoplasma genitalium & 1 & 3.3 & 19 & 19.8 & 7.9 & $<0.01$ \\
\hline N.gonorrhoeae & - & - & 2 & 2.1 & - & - \\
\hline Herpes simplex virus I, II & - & - & 4 & 4.2 & - & - \\
\hline Cytomegalovirus & - & - & 3 & 3.1 & - & - \\
\hline$H R V$ & 2 & 6.7 & 18 & 18.7 & 3.4 & $>0.05$ \\
\hline
\end{tabular}

Table VI. Flora of the uterine cavity in patients of the group I (abs. n., \%)

\begin{tabular}{|c|c|c|}
\hline \multirow{2}{*}{ Microorganisms } & \multicolumn{2}{|c|}{ Group I n=96 } \\
\hline & Abs. $\mathbf{n}$. & $\%$ \\
\hline Group B Streptococcus & 8 & 8.3 \\
\hline Enterococcus faecalis & 12 & 12.5 \\
\hline Group B Streptococcus + Enterococcus faecalis & 14 & 14.6 \\
\hline Prevotella melaninogenica & 23 & 23.9 \\
\hline Peptostreptococcus sp. + Prevotella melaninogenica & 19 & 19.8 \\
\hline Chlamydia trachomatis & 27 & 28.1 \\
\hline Ureaplasma urealyticum & 12 & 12.5 \\
\hline Mycoplasma genitalium & 17 & 17.7 \\
\hline N.gonorrhoeae & 2 & 2.1 \\
\hline
\end{tabular}

ciations of obligate anaerobes and Chlamydia trachomatis were found in $69(71.8 \%)$ of these patients; $29(30.2 \%)$ microaerophiles; 14 (14.6\%) - the combination of different species of opportunistic pathogens; in 19 (19.8\%) - the growth of monocultures of opportunistic pathogens in titers coming to $10 \times 6-10 \times 8$. The growth of monoculture, represented by group B Streptococcus was found in $8(8.3 \%)$ cases, Enterococcus faecalis - in 12 (12.5\%), Mycoplasma genitalium - in 17 (17.7\%). It is worth noting that obligate anaerobes and Chlamydia trachomatis were only found in the uterine cavity as an association.
The microbiota, consisting of viruses and bacteria, was found in patients of the group I when conducting a comprehensive microbiological analysis of the content of the uterine cavity. Whereas, separate opportunistic pathogens were predominant in a culture, in the titers exceeding $10^{4} \mathrm{CFU} / \mathrm{ml}$, in the same patient categories in case of culturing.

The analysis of the PCR test enabled to identify associations of various virus strains with $\mathrm{Myco-}$ and Ureaplasma, Chlamydia in 23 (23.9\%) patients of the group I. The predominance of Herpes simplex over CMV infection 
Table VII. PCR test of the sample from the uterine cavity in patients of the group I (abs. n., \%)

\begin{tabular}{ccc}
\hline \multirow{2}{*}{ Microorganisms } & \multicolumn{2}{c}{ Group I n=96 } \\
\cline { 2 - 3 } & Abs. $\mathbf{~}$. & \% \\
\hline Trichomonas vaginalis & - & 28 \\
\hline Chlamydia trachomatis & 28.2 & 19.8 \\
\hline Ureaplasma urealyticum & 19 & 25.0 \\
\hline Mycoplasma genitalium & 24 & 2.1 \\
\hline N.gonorrhoeae & 2 & 7.3 \\
\hline Herpes simplex virus I, II & 7 & 2.1 \\
\hline Cytomegalovirus & 2 & - \\
\hline HRV & - & \\
\hline
\end{tabular}

should be noted: $7(7.3 \%)$ and $2(2.1 \%)$, respectively (p $<0.05)$ (Table VII).

\section{DISCUSSION}

During analyses of microbiocenosis of vaginal microflora, cervical canal and uterine cavity women with infertility and sexually transmitted diseases in history formed a group with high index of persistent urogenital infection. It was confirmed by a number of international and native authors $[2,3,12]$.

Bacterial and viral contamination of endometrium is a consequence of insufficiency of immune system and nonspecific body defense system (complement system, phagocytosis) to eliminate infection factor fully, in order to restrict its spread by activation of T-lymphocytes (T-helpers, natural killers) and macrophages. Furthermore, mononuclear phagocytes, natural killers, T-helpers act in the focus of inflammation and produce different cytokines, that leads to impossibility to form local immunosuppression in the preimplantation period, which is needed in order to form protective barrier and prophylaxes of abruption of a fetus that is a half- heterogenous for mum. $[9,13,14]$.

According to a number of authors, the incidence of chronic endometritis in women with infertility is $12,3-$ $60,4 \%$, forming the only cause in $18,8 \%$ cases. $[3,5,6]$. According to publications of V.I.Krasnopolski [12], the genital infection, diagnosed by PCR investigation of content of cervical canal, uterine cavity of patients with chronic endometritis includes: chlamydiosis - 14,9\%, genital herpes - 33,6\%, ureaplasmosis - 37,8\%, mycoplasmosis - $11,6 \%$, cytomegaloviral infection $-18,9 \%$ of patients. Taking into account the up to date peculiarities of chronic endometritis course, with prevalence of latent forms of diseases, recently the main clinical symptom of chronic endometritis is dysfunction of reproductive function such as infertility, including non-effectiveness of assisted reproductive technologies. [4, 6]. The date collected by a complex analyses of microbiocenosis of vagina, cervical canal and uterine cavity of investigated patients are the same as in the results in literature $[16,17,18]$.

It is established, that the duration of microbial agent persistence in endometrium is the main factor, that is defining the stage of tissue damage and the severity of functional disorders of endometrium. The disorder of local resistance mechanisms leads to microbial agents persistence in endometrium, initializing chronical course of inflammatory process. Thus, the above mentioned data indicate the need of antibacterial, antiviral therapy depending on etiological factors in preconceptional period.

\section{CONCLUSIONS}

The predominance of the mixed microbiota, represented by various associations of opportunistic and common pathogens, was identified in infertile women with the past history of STIs after culturing samples from the uterine cavity. Chronic endometritis is caused by a persistent viral-bacterial infection in the uterine cavity, which differs in the species composition from the microbiota of the lower genital tract.

\section{REFERENCES}

1. Rowley J., Toskin I., Ndowa F. Global incidence and prevalence of selected curable sexually transmitted infections: 2008.

2. World Health Organization (WHO) Library Cataloguing-in-Publication Data Global strategy for the prevention and control of sexually transmitted infections: 2006 - 2015: breaking the chain of transmission. Geneva; World Health Organization. 2007.

3. Global' naya strategiya sektora zdravookhraneniya po infekcziyam, peredavaemy 'm polovy' $m$ putem, na 2016-20gg.: na puti k likvidaczii IPPP. [Global health sector strategy on sexually transmitted infections 2016-2021: Towards ending STIs]. Geneva:WH0. 2016: 60. (In Russian).

4. WHO guidelines for the treatment of Neisseria gonorrhoeae. WH0; 2016. http://apps.who.int/iris/bitstream/10665/246114/1/9789241549691eng.pdf.

5. Mavrov G.l ., Shherbakova Yu.V., Osi`ns`ka T.V. Novi` tni` metodi strimuvannya i'nfekczi j, shho peredayut sya statevim shlyakhom [Novel methods of containment of sexually transmitted infections]. Infectious diseases. 2019;1 (95): 4-10. (in Ukrainian).

6. Bondarenko G. M., Mavrov G. I., 0sinska 0. et al. Perinatal 'na i nvazi ya trichomonas vaginalis, yak problema reproduktivnoyi mediczin. [Perinatal invasion of trichomonas vaginalis as a problem of reproductive medicine] Journal of the National Academy of Medical Sciences of Ukraine. 2016;22( 3-4): 368-376. (in Ukrainian). 
7. Rishhuk S.V., Dushenkova T.A. Optimizacziya diagnostiki reproduktivno znachimy 'kh infekczij u polovy`kh par. [Optimization of diagnostics of reproductively significant infections in sexual couples ]. Terra Medica. 2016; 4: 20-33.

8. Rishhuk S.V., Vazhbin L. B., Akhunova N. R. et al. Prezentacziya Metodicheskikh rekomendaczij VOZ po khlamidijnoj infekczii. [Presentation of theWHO Guidelines for Chlamydial Infection] Bulletin of the Orenburg Scientific Center of the Ural Branch of the Russian Academy of Sciences. 2014. http://elmag.uran.ru:9673/Numbers/20144/Articles/ Rishchuk\%20et\%20al20144.pdf

9. Rishhuk S.V., Kakhiani E.I., Tatarova N.A. et al. Infekczionnovospalitel ny`e zabolevaniya zhenskikh polovy`kh organov: obshhie i chastny`e voprosy` infekczionnogo proczessa: uchebnoe posobie [Infectious and inflammatory diseases of the female genital organs: general and specific issues of the infectious process: a tutorial]. Publishing house of the North-Western State Medical University named after I. I. Mechnikov. 2016: 84.

10. Guffey M. B., Richardson B., Husnik M. et al. Sexually Transmitted Infections. 2014;90(5): 363-369.

11. Unanyan A. L., Snarskaya E. S., Lomonosov K. M. et al. Rol’ infekczij, peredavaemy 'kh polovy`m putem, $v$ razvitii zhenskogo besplodiya: strategii terapii i profilaktiki [The role of sexually transmitted infections in the development of female infertility: therapy and prevention strategies] Russian Journal of Skin and Venereal Diseases. 2014;5:59-62.

\section{ORCID and contributionship:}

Olena I. Krotik: 0000-0002-1677-6634 ${ }^{\text {A,B,C,DE,F }}$

\section{Conflict of interest:}

The Author declare no conflict of interest.

\author{
CORRESPONDING AUTHOR \\ Olena I. Krotik \\ Shupyk National Medical Academy of Postgraduate \\ Education of the Ministry of Health of Ukraine \\ 9 Dorohozhytska St., 04112 Kyiv, Ukraine \\ tel: +380678043311 \\ e-mail: krotik.elena@gmail.com
}

Received: 28.10 .2020

Accepted: 01.03 .2021

A - Work concept and design, B - Data collection and analysis, C - Responsibility for statistical analysis, D -Writing the article, $\mathbf{E}$-Critical review, $\mathbf{F}$ - Final approval of the article 